\title{
10 Blowing the Whistle Is Laden With Risk
}

\author{
Joseph McGlynn
}

Blowing the whistle is fraught with risks. They can be known or unknown, visible or invisible, certain or uncertain. When Peer Jacob Svenkerud (PJS) exposed the financial misdeeds of the CEO at Norsk Tipping (NT), he faced potential slander, shaming, and intimidation. And indeed he experienced all three. They took their toll on him physically and emotionallyeven financially. But, as with any whistleblower, his story illustrates how risk judgments reflect his values and priorities, and how his perceptions of risk likelihood and magnitude influenced his response to organizational wrongdoing. Prospect theory (Kahneman \& Tversky, 1979) posits that losses loom larger than gains when people make judgments of risk with uncertain outcomes. For PJS, the risk of being untrue to himself, as well as to others, finally outweighed his fears of retaliation.

PJS took on the risk of exposing organizational wrongdoing while working for an organization whose very existence, ironically, is grounded in risk. NT is a government-owned company, started in 1948, that offers lotteries, sports, and games of chance that prove enticing to Norwegians, with all profits supposedly channeled back to the country's sports and culture sectors. So NT seeks to encourage people to take on reasonable risks, both for themselves and for the greater good. PJS's own risk calculation concerned whether to alert the world to unethical behavior by NT's CEO. Once he acted on that decision, he encountered retaliation at both the personal and professional level. In subsequent interviews, PJS describes feeling isolated and unsupported by colleagues at NT. He even faced losing his job as well as suffering other financial and social repercussions.

Why would anyone hazard such risk? In PJS's case, it was perhaps to avoid an even greater risk: the risk of inaction. If he chose to ignore the wrongdoing, he risked losing an opportunity to discover, maybe even to define his true character-his deepest values and priorities-both to himself and to others. It was truly a watershed for him, a coming-of-age moment.

In the pages ahead, I describe some key concepts and dimensions of risk theories, highlight those elements of risk most relevant to whistleblowing, and use risk theory to illuminate the process of PJS's decision 
to blow the whistle, identifying the practical, logistical, and emotional factors that influenced his risk judgments and experience.

\section{Risk Perceptions and Judgments}

We humans, through our choices and actions, have a unique ability both to create and minimize risk in our lives (Slovic, 1987). Two questions guide our decisions about risk-taking: What is the likelihood of a bad result happening, and how bad a result might it be (Fischoff, Slovic, Lichtenstein, Read, \& Combs, 1978)? These two considerations reflect decision processes of risk as analysis and risk as feelings (Slovic, Finucane, Peters, \& MacGregor, 2004). The former approaches risk decisions very analytically, with logic, deliberation, and reasoning (Slovic \& Peters, 2006). The latter approaches them suprarationally, relying on experience, intuition, and instinct. We are always estimating both the probability and the magnitude of any risk (Sztompka, 1999).

All risk decisions involve three things: options, outcomes, and uncertainty (Fischoff et al., 1978). The quality and characteristics of these inputs are influenced by social norms, context, and the language used to describe them. For whistleblowers, risk inputs include their options (blow the whistle vs. remain silent), outcomes (e.g., retaliation, successful cessation of wrongdoing), and uncertainty (how likely, and how great, is the retaliation they may face). Although risk can be quantified, the perception of it is influenced by emotions. To conceptualize risk, it's necessary to identify the emotions that motivate risk-taking. Affective responses have a substantial influence on risk decisions. Higher positive affect increases perceptions of benefits and decreases perceptions of risk (Finucane, Alhakami, Slovic, \& Johnson, 2000).

Language choices and the message frames used to describe a threat also influence risk judgments and perceptions (Tversky \& Kahneman, 1981). The framing of events prompts different affective and cognitive reactions to risks (Cho, 2012). Language choices reflect the beliefs of the speaker, as a speaker's choice of message frames communicates a particular vantage point and shape the meaning of an event (Fairhurst, 2005). Language choices can influence perceptions of risk severity (McGlone, Bell, Zaitchik, \& McGlynn, 2013) and attributions of risk responsibility (McGlynn \& McGlone, 2018).

\section{Prospect Theory}

Most risk judgments involve our factoring in both our potential losses and our potential gains (Kahneman, 2012) - that is, our costs and benefits (Fischoff et al., 1978). According to prospect theory (Kahneman \& Tversky, 1979), when we evaluate our risks, any potential losses tend to outweigh any potential gains. Fearing loss, we tend to become increasingly 
risk-tolerant, or even risk-seeking. But when assessing the risks associated with our potential gains, we tend to be risk-averse because we want to avoid losing those gains. To avoid a possible perceived loss, people are more willing to take risks, and they show a higher tolerance for supporting risky behavior. Perceptions of gains and losses influence whistleblowers' risk judgments and decision to blow the whistle.

Emotions influence risk perceptions (Slovic, Finucane, Peters, \& MacGregor, 2002). Emotions of anger and fear play key roles in whether to blow the whistle (Gundlach, Douglas, \& Martinko, 2003). Fear increases risk aversion, while anger increases risk-seeking (Lerner, Gonzalez, Small, \& Fischoff, 2003; Lerner \& Keltner, 2000). Control and uncertainty are key drivers of emotional reactions to risk (Lerner et al., 2003, Lerner \& Keltner, 2000). As whistleblowers debate the risks of blowing the whistle, they must acknowledge the hazard of uncertainty as they navigate the unknown risks, costs, and benefits of their possible actions.

For risks with known probabilities of outcomes, such as casinos, the weather (well, sometimes), or even the games sponsored by NT, logic and statistical thinking suffice for reasonable risk decisions (Gigerenzer \& Gaissmaier, 2011). But for risk judgments with unknown outcomes, like whistleblowing, intuition and emotional responses are needed for effective risk judgments. Although emotional responses to risk influence judgments (Finucane et al., 2000), so does the whistleblowers' perception of the ability of their actions to create change and successfully stop the wrongdoing.

\section{The Extended Parallel Process Model}

The Extended Parallel Process Model (EPPM) of risk perception (Witte, 1994, Witte \& Allen, 2000) proposes that whether we engage in risk depends on our perceptions of both the threat itself (How severe is it? How personally susceptible are we?) and also our perception of our ability to change the situation (self-efficacy, response efficacy). If we perceive risk to be low, we're unlikely to try to enact changes. However, when we perceive threats to be high, we then consider our ability to create change through our actions. Specifically, we consider our own self-efficacy, our ability to successfully create change, and response efficacy, our perception of how effective our available responses will be.

Many whistleblowers feel powerless to affect change in their situation (Miceli, Near, \& Dworkin, 2008). In such cases, self-efficacy and response efficacy remain low. So instead of acting, these whistleblowers would choose simply to try to minimize their concern about the threat. For PJS, his decision to blow the whistle reflects his perception of both high threat severity and high confidence in his ability to create change through his actions. Without that confidence, he would have felt powerless. The risks that whistleblowers tolerate reflect how they perceive and prioritize potential gains, losses, and self-efficacy. 


\section{Whistleblowing and Risk}

Whistleblowing increases professional, personal, and reputation risks for whistleblowers. Whistleblowers report high levels of stress, anxiety, depression, and feelings of isolation (Miceli \& Near, 1992; Rothschild \& Miethe, 1999). Exposing organizational wrongdoing frequently presents "dire consequences to whistleblowers, to their careers, and to their personal lives as a result of their actions" (Johnson, 2003, p. 74). At its core, whistleblowing is an act of resistance (Rothschild \& Miethe, 1999). Because whistleblowers seek to create change (Near \& Miceli, 1995), it can make them threatening to organizations.

Context and personality differences also influence whether a potential whistleblower chooses to speak out. For example, people with a strong sense of public service are more apt to risk blowing the whistle (Brewer \& Selden, 1998; Perry \& Wise, 1990). Whistleblowers are also more likely to act when they feel affected personally (Near \& Miceli, 1985). Perceptions of the overall goodness or badness of an event strongly influence risk behaviors (Slovic et al., 2002). Whistleblowers are also much more likely to act when the wrongdoing is both consistent and recurring (Miceli et. al, 2008).

People who choose to blow the whistle put themselves in dangerous positions, frequently suffering organizational and individual repercussions (Rehg, Miceli, Near, \& Van Scotter, 2008). Perceptions of retaliation influence whistleblower behavior (Miceli et al., 2008). Whistleblowers feel isolation and often endure hardship from people both within and outside the organization (McGlynn \& Richardson, 2014). Previous research on whistleblowing and risk focuses largely on the risks of exposing organizational wrongdoing. However, each whistleblowing case is unique, since context and industry factors individualize them (Richardson \& McGlynn, 2011).

In the case of PJS, we learn that the risks facing prospective whistleblowers extend beyond possible retaliation. They can also come with choosing not to speak up.

\section{Risk in the Case of PJS}

Whistleblowers, such as PJS, must weigh the risks of blowing the whistle against the risks of remaining silent and possibly being complicit in the organizational wrongdoing. Some people remain silent out of selfdefense, thinking it lets them separate themselves from the wrongdoing. They basically attempt to shut down their thinking and feeling processes. PJS, more honest with himself, couldn't do that. In his narrative (Chapter 1 ), he asks himself five questions, weighing the practical and emotional consequences of speaking out:

Would blowing the whistle mean giving up a comfortable and prestigious life? Would I be able to get another job? Did I even have a 
choice now, given that I was working for a governmentally owned operation that had a monopoly on a tremendously profitable market? Was the only option to finally face myself and live with the consequences? Moreover, was a failure to face myself the real reason for the internal disorder that had shadowed me for years?

Here, he specifies with remarkable clarity the risks he confronts. These questions describe multiple types of risk, including personal risks ("giving up a comfortable and prestigious life"), professional risks ("Would I be able to get another job?"), and emotional risks ("Was a failure to face myself the real reason for internal disorder that had shadowed me for years?"). He also describes the double-edged nature of the risk ("Did I even have a choice now?") and the mounting urgency to make his choice ("Was the only option to finally face myself and live with the consequences?").

PJS's story illustrates various types of risk encountered by whistleblowers. His experience describes professional, financial, and social risks. PJS also describes risks to his own sense of self. His story portrays two risks, battling each other head-on. If he blows the whistle, he makes himself vulnerable from a professional and financial situation. But if he chooses to accept the wrongdoing and allow NT to continue flouting its national trust, he risks loss of all self-respect. These emotional, affective decision inputs frequently motivate actions (Slovic et al., 2006). Emotional responses to risk stimuli reflect the overall feeling of goodness or badness in choosing one's course of action (Finucane et al., 2000). PJS poignantly confesses:

You come to a point internally where you really have to take some tough decisions for yourself. And this was one of the decisive points of my professional life, in terms that-I had thought of the whole summer. What I did really defined me as a person-can I continue like this or can I do what I know, as a certainty, is the right thing to do? And that's-shall I practice what I preach? ... I concluded this is all about my character and what I do now.

For PJS, the threat of losing his self-approval, his dignity, finally outweighed professional and financial risks-to his job, to his farm, to his family.

PJS's decision to blow the whistle was motivated in part by his desire to make the invisible visible, to reveal to himself his potential or ideal self. He wishes, also, to avoid the negative feeling of unfulfillment, of potential wasted. He felt "as if a shadow were following me-a feeling of general unhappiness about where my life had taken me." This emotional context is critical to understanding the process of PJS's risk decision. He states the multi-dimensional nature of his risk decision when he says, eloquently, "You are your own value platform ... something you not only 
carry, but must face." The emotional discontent, or negative affect (Slovic \& Peters, 2006), that PJS felt for his current place in life, created a desire to avoid that outcome and to take a risk on creating a better outcome for himself. As he describes it, "But my unsettledness pressed on me, urging me to make some sort of radical life-change." This beautifully illustrates prospect theory's tenet that potential negative outcomes motivate riskseeking behavior (Kahneman \& Tversky, 1979).

PJS further describes the role of risk magnitude when evaluating the consequence of risk decisions: "What happens to the decision-making process in a company when critical voices are suppressed, when there is a feudal company culture that people quietly follow because the risk of speaking out seems too complicated and too consequential." Similarly, he later asks, "Was I a part of something that was unhealthy, and that, if it became public, would be a disaster?" Here, PJS acknowledges the risk of becoming complicit in the wrongdoing, not to mention its potential magnitude, expressing the duality of risk that whistleblowers face when they feel personally dirtied by the wrongdoing if they choose not to speak out.

Uncertainty motivates risk decisions (Kahneman \& Tversky, 1984). A key factor to PJS's decision to blow the whistle was a sense of the speed and velocity to the magnitude and existence of the organizational wrongdoing. He says: "I felt out of place, in the wrong place. My efforts seemed to lead nowhere. Pressure mounted as the outside media and other stakeholders kept on digging into possible 'company secrets.' I was there, defending them with rapidly increasing discomfort." In that last comment, he's acknowledging that perceptions of risk increase as the threat moves closer. These comments indicate his need, and readiness, to reduce the uncertainty and to make his decision, as does this one: "With more certainty, it started to become clear to me that my self-confidence and ability to walk with my head held high in all kinds of situations had become easier." He was "beyond the point of pretending. I was a man who knew too much, and I had reached a point where non-action was no longer an ethical option."

\section{Isolation and Duality of Support}

Even when successful at stopping the wrongdoing, whistleblowers often face risks of criticism and long-term social isolation from co-workers. And it can be disquietly inconsistent-a combination of private support but public alienation (McGlynn \& Richardson, 2014). PJS illustrates the mixed signals here: "The new chair of the board and the interim CEO knew about my role and both of them expressed support, assuring me 'You did the right thing' and 'We will protect you.' But those assurances failed to blot out my acute sense of isolation, nor did my guilt go away." During researcher interviews, PJS says he felt vindicated by an independent report from auditors, but that "What was more disturbing to me 
was that internally, the new permanent CEO never said that the whistleblower did the right thing." Whistleblowers are in positions where they need more support than they ever needed before, but more often than not they are ignored in public by the same people who support them privately.

PJS describes the difficulty of seeking and receiving support from colleagues, saying: "I had hoped that the new permanent CEO would say something in the nature of giving me support when I came to work. Well, I got a call from his secretary at quarter to 8 in the morning, saying that you need to come to NT now because the CEO wants to have a meeting. . . ." PJS talks specifically about the sense of isolation that whistleblowers risk: "I saw it as a big problem because I didn't get any local support. And, I think that I knew at that point in time that my time was over in NT." Here, PJS illustrates how the sense of isolation felt by whistleblowers ostracizes them from colleagues and threatens their former sense of self that was inseparable from their profession or their organization.

Whistleblowers may receive praise in private but may also be shunned in public by the same people (McGlynn \& Richardson, 2014). PJS offers a poignant description of the types and quality of support he received for exposing the wrongdoing at NT:

I had telephone calls nonstop and a lot of supportive telephone calls. And letters and other things as well which made me feel good. But, very few from the company itself, very few if any. Well, from my close allies there, I had supportive comments, but it was very silent from the HR and the CEO. They never called. They didn't call me in the afternoon to see how I was doing. I had a feeling that they really didn't care, and that they cared more about the people who were angry. I think they probably did.

In his account, PJS describes feeling that the people upset by his exposing of the issues at hand received greater attention and support from the CEO, even though he was the one who assumed the risk to call it out. PJS further articulates the duality of support received:

A month and a half earlier, he [the CEO] had said I was his greatest supporter, I did a good job, etc. Now, I felt I was a liability for him and for the company. This followed a pattern that I had read about. If you do blow the whistle, you have truly become a liability, no matter what you do.

He recalls a friend-a corruption expert-predicting just this isolation and lack of support. Here was that frightening prediction: "Imagine the feeling of being alone in a small boat, downstream on a small river, 
meeting a supertanker. That is how you will feel from now on. It will be you against everyone else!" Admitting that the isolation and lack of support had deleterious and engulfing effects on his morale, PJS says that "that feeling of being completely by yourself is sometimes-very overwhelming. And it just swamps you and overwhelms you."

\section{Social Stigma}

Whistleblowers often describe the lasting stigma left by their decision to blow the whistle (Richardson \& McGlynn, 2011). PJS acknowledges fearing just that fate: "My story would undoubtedly follow me for the rest of my life. Who would dare to trust a whistleblower?" And again: "I felt that my situation in NT became increasingly vulnerable, in that if I suddenly one day was without a job, who would hire a person that had been-that could be connected to such a scandal?" Even friends and coworkers tend to distance themselves from people who report unethical behavior. PJS says:

It follows you throughout your life, I am convinced of. And I am convinced of, in listening to other people's stories, that it does not bring very much good to your professional career because there will always be skeptics out there that will look at your history and pertaining that you will bring your past into the present and perhaps do the same thing again and that you constitute a risk.

Ironically, in choosing to engage in risk to expose the wrongdoing, PJS actually became a risk to the organization. He acknowledges the common negative fate of whistleblowers, saying "you're also influenced by all the stories that you hear about the fate of whistleblowers, that they variously become squeezed out of the organization eventually. It follows them throughout their lives."

He describes himself as a sort of pariah, unwanted by either side, and fearing that the effects will linger forward. Talking about the difficulty of finding suitable employment, he states: "But that is something that other whistleblowers communicate as being one of the major problems in getting rehired, for example. Would you want the person like this on board your company, that is perhaps your hidden enemy?" PJS worries that people see him as someone looking to hurt co-workers at every opportunity, saying that others may think of him as "a person where you never know where you stand and that will always be behind you with a hidden weapon, ready to stab you when you least expect it."

PJS later expounds on the unfortunate reaction from his co-workers in a situation in which he felt that they were working for the same side: "For me, it was a very sad ending to something I honestly thought we could have solved. But I probably was too naïve in terms of thinking that that would be the case." 


\section{Outcomes}

PJS's experience exposing wrongdoing by the CEO at NT echoes many of the negative outcomes reported in the whistleblowing literature (Near \& Miceli, 1995; Rothschild \& Miethe, 1999). "Everything I had heard about blowing the whistle seemed to come true," he says.

But, thankfully, the effects were not exclusively negative. As he embarked on a process of self-discovery throughout his ordeal, PJS also experienced significant personal growth, and with it, a gratifying sense of rebirth:

On the other side though, in terms of personal development, something radical happened during that whole period of time. I had become very clear about who I was and what I wanted to do. I had been very conscientious about my own value platform and that was not a platform that you could exercise whenever you chose. I had to exercise it every day, both at home and at work. So, I think I've become a much better human being and a much better leader just having gone through that process.

In this account, PJS describes the clarity he received from choosing to engage in the risk to blow the whistle. He discusses the personal development and radical change he experienced as the results of risk decision, citing his growth as a person, a leader, and a citizen. Reminding us of the driving motivation behind his actions, PJS sums it up this way: "I decided to do this because I thought if I did not, I would not be true to myself."

\section{Conclusion}

This analysis sought to apply risk theory and research to reveal key influences experienced by PJS in the whistleblowing process, to lend insight into the psychological mechanisms that motivated PJS's whistleblowing disclosure, and to describe risk factors that complicated his actions. He ultimately decided it was too big of a risk not to blow the whistle. For not to act was to acquiesce to the gnawing feeling of regret: it had been "as if a shadow were following me," "of failing to accomplish anything meaningful" (Chapter 1). Blowing the whistle reflected his openness to risk in the face of potential lost opportunity (Kahneman \& Tversky, 1979). For PJS, the lost opportunity associated with inaction in the face of wrongdoing posed a greater risk than any retribution or shaming.

Blowing the whistle is inherently risky, with unpredictable outcomes. On the one hand, exposing organizational wrongdoing is bound to incur retaliation, including threats, slander, and reputation costs (Bhal \& Dadhich, 2011). It's an all-too-common experience for whistleblowers (Miceli, Near, \& Dworkin, 2008). But as PJS's story illustrates, there are 
also risks to not blowing the whistle. By keeping quiet about suspected or acknowledged wrongdoing is to feel complicit in it and to feel the guilt that comes with discovering one's cowardice and compromised values.

PJS's example describes social, organizational, and identity dynamics that influence whistleblower risk judgments and behaviors. When assessing whistleblowing risk, people consider the likelihood of negative outcomes and the magnitude of costs of those outcomes occurring. Whistleblowers often acknowledge the possibility of retaliation and negative outcomes but sometimes decide they must act. In the case of PJS and NT, sometimes the safest course is to take a risk.

\section{References}

Bhal, K. T., \& Dadhich, A. (2011). Impact of ethical leadership and leaderMember exchange on whistle blowing: The moderating impact of the moral intensity of the issue. Journal of Business Ethics, 103(3), 485-496.

Brewer, G. A., \& Selden, S. C. (1998). Whistle blowers in the federal civil service: New evidence of the public service ethic. Journal of Public Administration Research and Theory, 8(3), 413-440.

Cho, H. (Ed.). (2012). Health communication message design: Theory and practice. Thousand Oaks, CA: Sage.

Fairhurst, G. T. (2005). Reframing The Art of Framing: Problems and prospects for leadership. Leadership, 1, 165-185.

Finucane, M. L., Alhakami, A., Slovic, P., \& Johnson, S. M. (2000). The affect heuristic in judgments of risks and benefits. Journal of Behavioral Decision Making, 13, 1-17.

Fischoff, B., Slovic, P., Lichtenstein, S., Read, S., \& Combs, B. (1978). How safe is safe enough? A psychometric study of attitudes towards technological risks and benefits. Policy Sciences, 9, 127-152.

Gigerenzer, G., \& Gaissmaier, W. (2011). Heuristic decision making. Annual Review of Pscyhology, 62, 451-482.

Gundlach, M. J., Douglas, S. C., \& Martinko, M. J. (2003). The decision to blow the whistle: A social information processing framework. Academy of Management Review, 28, 107-123.

Johnson, R. A. (2003). Whistleblowing: When it works and why. Boulder, CO: Lynne Rienner Publishers, Inc.

Kahneman, D. (2012). Thinking, fast and slow. New York: Farrar, Straus \& Giroux.

Kahneman, D., \& Tversky, A. (1979). Prospect theory: Analysis of decision under risk. Econometrica, 47, 263-291. https://doi.org/10.2307/1914185.

Kahneman, D., \& Tversky, A. (1984). Choices, values, and frames. American Psychologist, 39, 341-350.

Lerner, J. S., Gonzalez, R. M., Small, D. A., \& Fischoff, B. (2003). Effects of fear and anger on perceived risks of terrorism: A national field experiment. Psychological Science, 14(2), 144-150.

Lerner, J. S., \& Keltner, D. (2000). Beyond valence: Toward a model of emotionspecific influences on judgement and choice. Cognition and Emotion, 14(4), 473-493. 
McGlone, M. S., Bell, R. A., Zaitchik, S. T., \& McGlynn III, J. (2013). Don't let the flu catch you: Agency assignment in printed educational materials about the H1N1 influenza virus. Journal of Health Communication, 18, 740-756. https://doi.org/10.1080/10810730.2012.727950.

McGlynn, J., \& McGlone, M. S. (2018). Desire or disease? Framing obesity to influence attributions of responsibility and policy support. Health Communication. https://doi.org/10.1080/10410236.2018.1431025.

McGlynn III, J., \& Richardson, B. K. (2014). Private support, public alienation: Whistle-blowers and the paradox of social support. Western Journal of Communication, 78, 213-237. https://doi.org/10.1080/10570314.2013. 807436.

Miceli, M. P., \& Near, J. P. (1992). Blowing the whistle: The organizational and legal implications for companies and employees. New York: Lexington Books.

Miceli, M. P., \& Near, J. P. (1994). Relationships among value congruence, perceived victimization, and retaliation against whistle-blowers. Journal of Management, 20, 773-794.

Miceli, M. P., Near, J. P., \& Dworkin, T. M. (2008). Whistle-blowing in organizations. New York: Routledge.

Near, J. P., \& Miceli, M. P. (1985). Organizational dissidence: The case of whistleblowing. Journal of Business Ethics, 4, 1-16.

Near, J. P., \& Miceli, M. P. (1995). Effective whistle-blowing. Academy of Management Review, 20, 679-708.

Perry, J. L., \& Wise, L. R. (1990). The motivational bases of public service. Public Administration Review, 50, 367-373.

Rehg, M. T., Miceli, M. P., Near, J. P., \& Van Scotter, J. R. (2008). Antecedents and outcomes of retaliation against whistle-blowers: Gender differences and power relationships. Organization Science, 19, 221-240.

Richardson, B. K., \& McGlynn, J. (2011). Rabid fans, death threats, and dysfunctional stakeholders: The influence of organizational and industry contexts on whistle-blowing cases. Management Communication Quarterly, 25, 121-150. https://doi.org/10.1177/0893318910380344.

Rothschild, J., \& Miethe, T. D. (1999). Whistle-blower disclosures and management retaliation: The battle to control information about organization corruption. Work and Occupations, 26, 107-128.

Slovic, P. (1987). Perceptions of risk. Science, 236, 280-285.

Slovic, P., \& Peters, E. (2006). Risk perception and affect. Current Directions in Psychological Science, 15(6), 322-325.

Slovic, P., Finucane, M. L., Peters, E., \& MacGregor, D. G. (2002). The affect heuristic. In T. Gilovich, D. Griffin, \& D. Kahneman (Eds.), Heuristics and biases: The psychology of intuitive judgment (pp. 397-420). New York: Cambridge University Press.

Slovic, P., Finucane, M. L., Peters, E., \& MacGregor, D. G. (2004). Risk as analysis and risk as feelings: Some thoughts about affect, reason, risk, and rationality. Risk Analysis, 24(2), 311-322.

Sztompka, P. (1999). Trust: A sociological theory. Cambridge: Cambridge University Press.

Tversky, A., \& Kahneman, D. (1981). The framing of decisions and the psychology of choice. Science, 211, 453-458. 


\section{Joseph McGlynn}

Witte, K. (1994). Fear control and danger control: A test of the Extended Parallel Process Model. Communication Monographs, 61, 113-134. https://doi. org/10.1080/03637759409376328.

Witte, K., \& Allen, M. (2000). A meta-analysis of fear appeals: Implications for effective public health campaigns. Health Education and Behavior, 27, 608632. https://doi.org/10.1177/109019810002700506. 